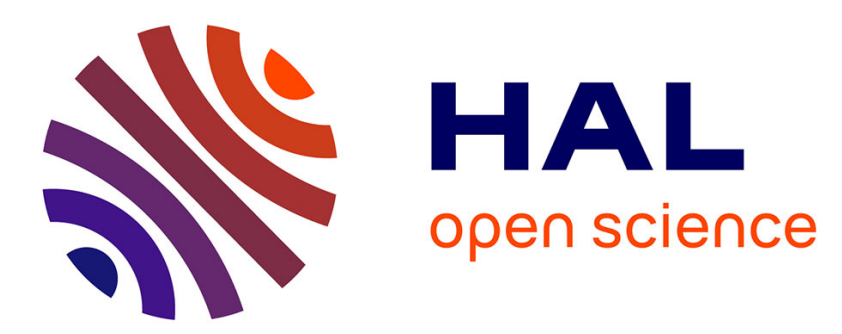

\title{
Patients' experiences and preferences with co-managed care in a cataract pathway
}

Ellen Joan van Vliet, Nic Reus, Walter Sermeus, Jan Vissers, Johannes Sol, Hans G Lemij

\section{- To cite this version:}

Ellen Joan van Vliet, Nic Reus, Walter Sermeus, Jan Vissers, Johannes Sol, et al.. Patients' experiences and preferences with co-managed care in a cataract pathway. British Journal of Ophthalmology, 2010, 94 (10), pp.1363. 10.1136/bjo.2009.169672 . hal-00557338

\section{HAL Id: hal-00557338 \\ https://hal.science/hal-00557338}

Submitted on 19 Jan 2011

HAL is a multi-disciplinary open access archive for the deposit and dissemination of scientific research documents, whether they are published or not. The documents may come from teaching and research institutions in France or abroad, or from public or private research centers.
L'archive ouverte pluridisciplinaire HAL, est destinée au dépôt et à la diffusion de documents scientifiques de niveau recherche, publiés ou non, émanant des établissements d'enseignement et de recherche français ou étrangers, des laboratoires publics ou privés. 


\section{Patients' experiences and preferences with co-managed care in a cataract}

pathway

Ellen J. van Vliet, ${ }^{1,2}$ Nicolaas J. Reus, ${ }^{3}$ Walter Sermeus,,${ }^{1}$ Jan M.H. Vissers, ${ }^{4}$ Johannes C.A. Sol, ${ }^{3}$ Hans G. Lemij ${ }^{1,3}$

${ }^{1}$ School of Public Health, Faculty of Medicine, Catholic University Leuven, Leuven, Belgium

${ }^{2}$ Rotterdam Ophthalmic Institute, Rotterdam, the Netherlands

${ }^{3}$ Rotterdam Eye Hospital, Rotterdam, the Netherlands

${ }^{4}$ Institute of Health Policy and Management, Erasmus University Medical Center

Rotterdam, Rotterdam, the Netherlands

\section{Correspondence:}

Ellen J. van Vliet

Rotterdam Ophthalmic Institute, P.O. Box 70030

3000LM Rotterdam, the Netherlands

Tel: +31104023440

Fax: +31104017655

E-mail: ellen.vanvliet@oogziekenhuis.nl

Key words: Cataract surgery, patient satisfaction, clinical pathway

Word count: 2667 words

Abstract: 206 words

Tables and figures: 3 tables, 2 figures $(1 a+b, 2)$ 


\section{ABSTRACT}

Background/aims: Co-managed care in cataract pathways allows ophthalmologists more time to treat other patients. However, little is known how patients experience pathways that greatly reduce the amount of time spent with ophthalmologists.

Purpose: To determine experiences and preferences of cataract patients with comanaged postoperative care.

Methods: In a nested-case control study we included 194 patients who received their first-day review and final review by an ophthalmologist and 289 patients who received a telephone first-day review by a nurse and a final review by an optometrist. The Consumer Quality Index Cataract questionnaire was used to measure patients' experiences with the quality of care after uncomplicated first eye cataract surgery. Results: Patients in the co-managed care pathway reported similarly good experiences with the quality of care as patients that received their reviews by an ophthalmologist. Patients who were reviewed by a nurse reported to prefer the same first-day review method significantly more often than those who were reviewed by an ophthalmologist. Most patients preferred the final review by an ophthalmologist.

Conclusion: Overall, cataract patients highly rated co-managed care pathways without any postoperative contact with ophthalmologists. Nevertheless, patients still preferred ophthalmologists for their final review to optometrists. Any added patients' benefits should be clearly determined before substituting activities from ophthalmologists to other care professionals. 


\section{INTRODUCTION}

Cataract surgery is the most frequently performed ophthalmic surgical procedure in the Western world.[1-3] While the number of ophthalmologists is relatively stable, the demand for cataract surgery is rising due to an aging population and an expanding life expectancy.[4, 5] This calls for cataract pathways that are more easily accessible.[6, 7] To this end, one may need alternatives to the traditional care, such as co-managed care, to allow clinicians more time to see and treat other patients. Co-managed care involves the transfer of care responsibilities by clinicians to other care professionals.[8] An example of co-managed care is providing a telephone review by a trained nurse one day after surgery instead of having the patient return to the hospital for follow-up by the ophthalmologist. Various studies have shown that first-day telephone reviews by trained nurses provide safe and effective alternatives to routine reviews by ophthalmologists. $[9,10]$ A second example of co-managed care is having an optometrist, rather than an ophthalmologist, performing the final postoperative refraction and eye examination. Final reviews by optometrists are a safe and feasible alternative to the ophthalmologist-alone follow-up. $[8,11]$ In the Rotterdam Eye Hospital in the Netherlands, access for patients to the cataract pathway increased by more than $40 \%$ after introducing postoperative care by nurses and optometrists in the cataract pathway.[12]

Thus, co-managed care projects have been shown to increase efficiency while being safe and feasible.[8-12] However, little is known how patients experience such practices, as the amount of time spent with their ophthalmologist is greatly reduced. The aim of this study was to determine the patients' perspective of a cataract pathway that left out all postoperative contact with ophthalmologists. Therefore, we formulated the following research questions:

1. What are the effects of co-managed care pathways on patients' experiences with the quality of care? 
2. What are the preferences of patients with respect to co-managed care by nurses and optometrists and more traditional care by ophthalmologists?

\section{METHODS}

\section{Study design and patient groups}

We conducted a nested case control study on 1140 patients who were selected from a prospective cohort of 7645 patients who underwent first eye cataract surgery at the Rotterdam Eye Hospital (the Netherlands) between January 2007 and September 2008. All patients in the cohort were operated on by means of phacoemulsification with intraocular lens implantation performed as a same-day outpatient procedure. To minimize any effect of previous experiences on the patient's perspective on the cataract pathway, we included only patients who underwent uncomplicated first eye cataract surgery and did not suffer from any ocular comorbidity $(n=5275)$ (see Figure 1a).[13]

We selected a random sample $(n=1740)$ of this subgroup, using the random sample generator of Statistical Package for Social Sciences (SPSS) 16.0®. We sent all patients in this sample a Consumer Quality Index (CQI) Cataract questionnaire to measure their experiences with the quality of cataract care.[14] The questionnaires were sent to the patients' home addresses 2 months after surgery. No reminders were sent. Then we consulted the hospital's database to determine what postoperative care each patient had received. The postoperative care in the Rotterdam Eye Hospital comprised two review moments: one on the day after surgery and a final one 4 weeks later. We included only those patients $(n=1140)$ who received either both reviews by an ophthalmologist (control group; $n=515$ ) or who received the first-day telephone review by a trained nurse and the final review by an optometrist (experimental group; $n=625$ ) (see Figure 1a).

Seven hundred and forty patients (65\%) returned the questionnaire (see Figure 1b). Following the CQI protocol,[15] we excluded 185 of these 740 patients from the 
analysis. In addition, 72 patients were excluded because they either did not answer the questions about their postoperative review $(n=27)$ or because the review they reported did not match the one registered in the hospital's database $(n=45)$. Therefore, we included 194 (38\%) patients in the control group and 289 (46\%) patients in the experimental group.

We consulted the hospital's database to determine the age and gender of all 1140 patients. No statistical differences were found in age (independent samples t-test, $P=0.30)$ or gender (chi-square test, $P=0.35)$ between the included $(\mathrm{n}=483)$ and excluded ( $n=657$ ) patients. The health status and level of education were measured with the CQI Cataract questionnaire (see below for more details). One of the authors (EJVV) analysed the patient records of all 483 included patients for the preoperative and postoperative corrected distance visual acuity, intended and achieved refractive error. The corrected distance visual acuity was measured to a maximum of 1.0 (decimal Snellen equivalent). To determine the average corrected distance visual acuity, we converted acuity expressed as decimal Snellen equivalent to LogMAR equivalent and then determined the average of the LogMAR values.[16] The patients in the control group reported significantly more often having a bad health, having a lower level of education, and they also had a lower preoperative and postoperative visual acuity and a larger difference between intended and achieved refractive error compared to the patients in the experimental group (Table 1).

\section{Intervention: review methods in the cataract pathway}

As stated above, the cataract pathway we have studied presently had a first review one day after surgery and a second one four weeks later. Both reviews had two possibilities: one with an ophthalmologist and one without an ophthalmologist (i.e., comanaged care) conducting the reviews. The co-managed review methods were gradually introduced between February 2005 and October 2006. 
During the first-day review, patients were screened for any early-postoperative complications by either an in-hospital review by the ophthalmologist or a telephone review by a trained nurse. During in-hospital reviews (requiring patients to visit the hospital), ophthalmologists measured the visual acuity and performed a slitlamp examination. During telephone reviews, nurses interviewed patients using a standard checklist. All patients were eligible for receiving a telephone review. Allocation of patients to either of the two review methods was based on the availability of nurses and the surgeon's level of training. Residents performed 65 of the 483 surgeries. These 65 patients were reviewed in the hospital by the ophthalmologist and/or resident. For the other 129 patients in the control group, the nursing capacity was insufficient the day after surgery and they were reviewed in the hospital as well by the ophthalmologist. The 289 patients in the experimental group were operated by an ophthalmologist and received a telephone review.

During the second (and final) review, both the refractive error and the corrected distance visual acuity were determined. In addition, the operated eye was examined with the slitlamp. We studied two alternatives: an in-hospital review by the ophthalmologist and an in-hospital review by an optometrist. Both visits required that the patient visited the hospital. All patients were eligible for receiving their final review by an optometrist. Allocation of patients to either of the two review methods was based on the availability of optometrists. For the 194 patients in the control group the optometrist capacity was insufficient and they received an in-hospital review by their ophthalmologist. The 289 patients in the experimental group received an in-hospital review by an optometrist.

\section{Instrument: Consumer Quality Index Cataract Questionnaire}

We used the validated CQI Cataract questionnaire to measure patients' experiences with the quality of care in the cataract pathway (from the diagnostic phase through the final review) (see Figure 2).[14] In addition to the standard CQI questions, we added a 
question about the patient's perception whether he or she had enough contact with the ophthalmologist in the cataract pathway. We also added two questions about whom they saw during the first and second reviews. To analyse the patients' experiences and preferences with respect to co-managed care and traditional care, we added six questions that assessed how patients graded the communication with their care provider (i.e., ophthalmologist, nurse or optometrist) during the first-day and final reviews and one question about the review method they would prefer for a future second eye cataract surgery. Possible answers were based on a binominal scale (yes/no) or on a 4-point Likert scale (1=never/definitely not; $2=$ sometimes/probably not; 3=often/probably; 4=always/definitely). Global ratings for overall care delivery were allowed to range from 0 to 10 , with a score of 10 indicating the best possible care.

\section{Statistical analysis}

Ratings of the communication with the ophthalmologist were represented as a mean that was calculated from the patients' scores on questions 1 to 8 in the questionnaire (see Figure 2).[14] All ordinal variables with multiple answering categories (i.e., 4-point Likert scales and ratings from 0 to 10 ) were analysed with Mann-Whitney tests. All dichotomous variables were analysed with chi-square tests. For each patient, we determined if the review method that the patient reported as preferable for any future second eye cataract surgery corresponded with the actual received review method. We used a chi-square test to analyse if the experimental group differed from the control group in its choice to have the same review method again.

As the study used non-equivalent groups (see Table 1), we used multiple regression analysis to adjust for the effects of seven confounders (age, health, gender, education, LogMAR equivalent of the postoperative corrected distance visual acuity, number of increased visual acuity lines and difference between intended and achieved refractive error in diopters) on each outcome variable.[14, 17-19] The allocated method of postoperative care (i.e., control group with traditional review methods and 
experimental group with co-managed review methods) and the seven confounders were entered into the equation. We recoded health and education into dichotomous variables.[14] The variable health had two categories "good health" (containing the answering categories "excellent", "very good" and "good") and "bad health" (containing the answering categories "fair" and "poor"). The variable education had two categories "low education" (i.e., no education or primary education) and "high education" (i.e. high school or higher). We conducted a multiple linear regression analysis to adjust for the confounders on the ordinal outcome variables, and multiple logistic regression analysis to adjust for the confounders on the dichotomous outcome variables.[20]

In the present study, a P-value of $<0.05$ was considered statistically significant. All analyses were conducted using SPSS16.0®.

\section{RESULTS}

In general, patients in both arms of the study reported a very positive experience with the quality of care (see Table 2). In particular, patients rated the communication with the ophthalmologists in the entire cataract pathway almost always good (mean of 3.7 in traditional pathway and 3.8 in co-managed care pathway; $P=0.33$ ) and were almost always willing to recommend the hospital to family and friends (3.9 in both groups; $P=$ 0.14). However, patients who received both reviews by an ophthalmologist tended to grade their ophthalmologist somewhat higher $(9.1$ versus $8.9, P=0.07)$ and to report slightly more often that they had spent enough time with their ophthalmologist $(96 \%$ versus $92 \%, P=0.08)$. In contrast, patients who received their reviews in the comanaged care pathway reported statistically significantly more often that they received postoperative instructions (74\%) than patients who had both reviews by an ophthalmologist $(61 \%)(P<0.01)$. Although there were statistically significant differences between the control and experimental group in health, level of education, postoperative corrected distance visual acuity, number of increased visual acuity lines and difference between intended and achieved refractive error (Table 1), these 
differences did not statistically significantly affect the reported experiences between the control and experimental group (Table 2).

Most patients reported that they had positively experienced their first-day review and final review, independent of the review method they had undergone (Table 3). Patients felt reassured and thought that the care providers (ophthalmologist, nurse or optometrist) listened attentively and provided clear information. Patients who were reviewed by a nurse reported to prefer the same first-day review method significantly more often than those who were reviewed the first day by an ophthalmologist $(87 \%$ versus $72 \%$, respectively; $P<0.01)$. Patients who had their final review by an ophthalmologist as well as those who had their final review by an optometrist reported to prefer to have their final review performed by an ophthalmologist (95\% versus $58 \%$, respectively; $P<0.01)$.

\section{DISCUSSION}

Patients who did not have any contact with ophthalmologists after uncomplicated cataract surgery reported similarly good experiences with the quality of care as patients who received all postoperative reviews by ophthalmologists. However, the preferences

of patients did not entirely match their reported experiences. Despite good experiences with optometrists, most patients still preferred an ophthalmologist for their final review.

A possible explanation for the difference between the patients' positive experiences with and lack of preference for a final review by an optometrist may be that patients did not experience enough benefit in return for not seeing an ophthalmologist during their visit to the hospital. In contrast, we found that patients who received a telephone first-day review by a nurse even more often preferred the same review method than those who were reviewed the first day by an ophthalmologist. In this case, not having to travel to the hospital may have outweighed the fact that patients did not see an ophthalmologist. 
Other studies, all using a conjoint analysis to identify patients' preferences, have shown that patients tend to prefer care providers with a lower level of training, e.g., optometrist, resident or nurse, to physicians if travel time or waiting times are shorter or if they can determine the moment of consultation themselves.[21-23] Therefore, to increase a patient's preference for a final review by an optometrist, it may be necessary to offer an extra service. For example, final reviews by optometrists outside the hospital close to patients' homes might increase their preferences for this kind of review.

In our study, patients who were reviewed by nurses and optometrists reported more often than those who were reviewed by an ophthalmologist to have received postoperative instructions. This may have been due to the nurses' use of a standardized list of questions and instructions. Therefore, perhaps ophthalmologists ought to use standardized information as well.

Patients in the experimental group had a higher postoperative corrected distance visual acuity than patients in the control group. On the other hand, patients in the control group showed more improvement in their visual acuity. In multiple regression analyses, neither of these confounders affected patients' experiences with the quality of care. A reason for this may be that patient satisfaction is not primarily affected by vision outcome, but rather by attentiveness and responsiveness of the ophthalmologist.[24] In fact, Nijkamp et al have shown [25] that patient satisfaction after cataract surgery is more strongly correlated with the care given to patients than their medical outcomes.

In our study, nurse and optometrist capacity, rather than clinical decision making, largely determined the method of review that patients received. To more effectively meet the demand for co-managed care, the Rotterdam Eye Hospital has now expanded the capacity of nurses and optometrists. We feel that, when introducing co-managed care pathways, enough well-trained staff should be allocated to sufficiently match capacity and demand. 
In the past, little attention has been paid to patients' preferences in co-managed medical care projects that aim to increase efficiency. To our knowledge, the present study is the first to measure both the experiences and the preferences of patients that received co-managed care after cataract surgery. We have presently shown that the way patients experience the quality of cataract surgery care is not affected by any postoperative contact with their ophthalmologist. This strengthens the choice for implementing co-managed care to meet the current shortage in ophthalmologists. When asked explicitly, however, the patients had rather visit their own ophthalmologists postoperatively than the optometrists. When the patients experienced an apparently added benefit of co-managed care (i.e., not having to travel to the hospital for a review, but being interviewed by a nurse on the telephone), they preferred co-managed care. We therefore think that whenever co-managed care is introduced, an added value for the patients needs to be determined clearly.

We think that healthcare organizations should strive for efficient comanagement that meets the shortage of ophthalmologists, and that patients also highly value and prefer. More research is necessary to increase our understanding how to organize efficient cataract pathways that patients still favour. 


\section{Acknowledgements of competing interests}

None.

\section{Funding}

This study was supported by the Rotterdam Eye Hospital Research Foundation, Rotterdam, the Netherlands.

\section{Ethical approval}

Our research study adhered to the tenets of the Declaration of Helsinki. The institutional human experimentation committee of the Erasmus Medical Centre Rotterdam approved the study.

\section{Copyright License Statement}

The Corresponding Author has the right to grant on behalf of all authors and does grant on behalf of all authors, an exclusive licence on a worldwide basis to the BMJ Publishing Group Ltd and its licensees, to permit this article (if accepted) to be published in British Journal of Ophthalmology and any other BMJGPL Group products and to exploit all subsidiary rights, as set out in our licence (http://group.bmj.com/products/journals/instructions-for-authors/licence-forms). 


\section{References}

1. Klaver C, Wolfs CC, Vingerling JR, et al. Age-specific prevalence and causes of blindness and visual impairment in an older population: the Rotterdam Study. Arch Ophthalmol 1998; 116:653-8.

2. Javitt JC, Kendix M, Tielsch JM, et al. Geographic variation in utilization of cataract surgery. Med Care 1995;33:90-105.

3. The Royal College of Ophthalmologists. Cataract Surgery Guidelines. 2004, London. http://www.rcophth.ac.uk/docs/publications/publishedguidelines/FinalVersionGuidelinesApril2007Updated.pdf (accessed 29 July 2009).

4. Brian $\mathrm{G}$ and Taylor H. Cataract blindness - challenges for the 21st century. Bulletin of the World Health Organization 2001;79:249-256.

5. Congdon N, Vingerling JR, Klein BE, et al. Prevalence of cataract and pseudophakia/aphakia among adults in the United States. Arch Ophthalmol 2004;122:487-94.

6. Gogate PM. Small incision cataract surgery: Complications and mini-review. Indian J Ophthalmol 2009;57:45-9.

7. NHS Executive. Action on Cataracts, Good Practice Guidance. 2000, London. http://www.dh.gov.uk/en/Publicationsandstatistics/Publications/PublicationsPolic yAndGuidance/DH_4005637 (accessed 29 July 2009).

8. Revicki DA, Brown RE and Adler MA. Patient outcomes with co-managed postoperative care after cataract surgery. J Clin Epidemiol 1993;46:5-15.

9. Mandal K, Dodds SG, Hildreth A, et al. Comparative study of first-day postoperative cataract review methods. J Cataract Refract Surg 2004;30:196671. 
10. Herbert EN, Gibbons H, Bell J, et al. Complications of phacoemulsification on the first postoperative day: can follow-up be safely changed? J Cataract Refract Surg 1999;25:985-8.

11. Booth A, Walters G, Cassels-Brown A, et al. Shared care postoperative management of cataract patients. Br J Ophthalmol 1998;82:332.

12. Vliet van EJ, Sermeus W, Gaalen van CM, et al. Efficacy and efficiency of a lean cataract pathway: a comparative study. Qual Saf Health Care 2009;in press.

13. Desai P, Minassian DC and Reidy A. National cataract surgery survey 1997-8: a report of the results of the clinical outcomes. Br J Ophthalmol 1999;83:133640.

14. Stubbe JH, Brouwer W and Delnoij DM. Patients' experiences with quality of hospital care: the Consumer Quality Index Cataract Questionnaire. BMC Ophthalmology, 2007;7:14 doi:10.1186/1471-2415-7-14 [published Online First: 19 September 2007].

15. Sixma $H$, Hendriks $M$, Boer de D, et al. Handboek CQI Metingen: richtlijnen en voorschriften voor metingen met een CQI meetinstrument, Deel 2: Opschoning databestanden en (vergelijkende) analyses. 1 November 2008. http://www.centrumklantervaringzorg.nl/fileadmin/site/ckz/documenten/procedur es/Handboek_CQI_Metingen_Deel_2_opschoning_en_analyse_van_databest anden_versie_2.0_november_2008-2.pdf (accessed 29 July 2009).

16. Holladay JT. Proper Method for Calculating Average Visual Acuity. $J$ Refract Surg 1997; 13:388-91.

17. Zaslavsky AM and Zaborski LB. Adjusting Performance Measures to Ensure Equitable Plan Comparisons. Health Care Financing Review 2001;22:109-126.

18. O'Malley AJ, Zaslavsky AM, Elliot MN, et al., Case-mix adjustment of the CAHPS Hospital Survey. Health Serv Res 2005;40:2162-81. 
19. Brouwer W, Sixma H, Triemstra M, et al., Kwaliteit van zorg rondom een staaroperatie vanuit het perspectief van patiënten. NIVEL, 2006.

http://www.centrumklantervaringzorg.nl/fileadmin/site/ckz/publicaties/Kwaliteitvan-zorg-rondom-een-staaroperatie-vanuit-het-perspectief-van-patienten2006.pdf (accessed 29 July 2009).

20. Sixma H, Hendriks M, Boer de D, et al. Handboek CQI Ontwikkeling: richtlijnen en voorschriften voor de ontwikkeling van een CQI meetinstrument. 1 November 2008.

http://www.centrumklantervaringzorg.nl/fileadmin/site/ckz/documenten/procedur es/Handboek_CQI_Ontwikkeling_versie_2.0_november_2008-2.pdf (accessed 29 July 2009).

21. Bhargava JS, Bhan-Bhargava A, Foss AJ, et al. Views of glaucoma patients on provision of follow-up care; an assessment of patient preferences by conjoint analysis. Br J Ophthalmol 2008;92:1601-5.

22. Ross MA, Avery AJ and Foss AJ. Views of older people on cataract surgery options: an assessment of preferences by conjoint analysis. Qual Saf Health Care 2003;12:13-7.

23. Jakobs C, Nobelen van D and Broerse A. Consumentenopvattingen over taakherschikking in de gezondheidszorg, Achtergrondstudie uitgebracht door de Raad voor de Volksgezondheid en Zorg bij het advies Taakherschikking in de gezondheidszorg. 2002, Raad voor de Volksgezondheid en Zorg: Zoetermeer.

p. 78. http://www.rvz.net/data/download/consumentenbond.pdf (accessed 29 July 2009).

24. Johnston R. The determinants of service quality: satisfiers and dissatisfiers. International Journal of Service Industry Management 1995;6:53-71

25. Nijkamp MD, Nuijts RM, Borne B, et al. Determinants of patient satisfaction after cataract surgery in 3 settings. J Cataract Refract Surg 2000;26:1379-88 


\section{Titles and legends to tables and figures}

Table 1 Patient characteristics of the control group (first-day review and final review conducted by ophthalmologists, i.e., traditional care pathway) and the experimental group (telephone first-day review by a nurse and final review by an optometrist, i.e. comanaged care pathway).

Table 2 Patients' experiences with quality of care in a cataract pathway with postoperative contact with ophthalmologists (control group with first-day review and final review conducted by ophthalmologists, i.e., traditional care pathway) and a cataract pathway without postoperative contact with ophthalmologists (experimental group with telephone first-day review by a nurse and final review by an optometrist, i.e. co-managed care pathway).

Table 3 The first-day review and final review 4 weeks after surgery: Comparison of patients' experiences with the care provider (ophthalmologist, nurse or optometrist) and patients' preferences for a review method for a future second eye cataract surgery between the control group (ophthalmologist conducted first-day and final review, i.e., traditional care pathway) and the experimental group (nurse conducted first-day review and optometrist conducted final review, i.e., co-managed care pathway). 
Figure 1; 1a Selection of a random sample of 1140 patients without ocular comorbidity, after uncomplicated first eye cataract surgery, from a prospective cohort of 7645 cataract patients. The control group consists of 515 cataract patients who received care in a traditional care pathway with the first-day and final review conducted by ophthalmologists. The experimental group consists of 625 cataract patients who received care in a co-managed care pathway with a telephone first-day review by a nurse and a final review by an optometrist. 1b Sample of 1140 patients, who received a Consumer Quality Index (CQI) Cataract Questionnaire to measure patients' experiences with the quality of care in a traditional care pathway (control group, included $n=194 / 515,38 \%$ ) and in a co-managed care pathway (experimental group, included $n=289 / 625,46 \%)$.

* Questions 15-24 can be found in Figure 2

Figure 2 A selection of questions of the Consumer Quality Index Cataract questionnaire with answer categories. We used these questions to measure patients' experiences with quality of care in the traditional care pathway with the first-day and final review conducted by ophthalmologists (control group) and in a co-managed care pathway with a telephone first-day review by nurse and a final review by optometrist (experimental group). Questions 10 and 15 through 24 (denoted by asterisks) are additional questions to assess the patients' experiences with and preferences for the different review methods in the cataract pathway. 
Table 1

\begin{tabular}{|c|c|c|c|}
\hline & $\begin{array}{l}\text { Control } \\
\text { group } \\
n=194\end{array}$ & $\begin{array}{c}\text { Experimental } \\
\text { group } \\
n=289\end{array}$ & $P$-value \\
\hline Age $^{*}$ & $71.2(10.1)$ & $70.3(10.2)$ & $0.32 \dagger$ \\
\hline $\operatorname{Men}^{* *}$ & $99(51.0 \%)$ & $132(45.7 \%)$ & $0.25 \ddagger$ \\
\hline Self-reported health status** & & & $<0.01 \ddagger$ \\
\hline Good health & $147(75.8 \%)$ & $252(87.2 \%)$ & \\
\hline Bad health & $47(24.2 \%)$ & $37(12.8 \%)$ & \\
\hline Education ${ }^{* *}$ & & & $0.04 \ddagger$ \\
\hline Low education & $82(42.3 \%)$ & $95(32.9 \%)$ & \\
\hline High education & $112(57.7 \%)$ & $194(67.1 \%)$ & \\
\hline Preoperative corrected distance visual acuity (decimal equivalent) ${ }^{*}$ & $0.26(0.30)$ & $0.36(0.45)$ & $<0.01 \dagger$ \\
\hline Postoperative corrected distance acuity (decimal equivalent) ${ }^{*}$ & $0.82(0.72)$ & $0.88(0.77)$ & $<0.01 \dagger$ \\
\hline Patients with $\geq 2$ increased number of visual acuity line $(s)^{* *}$ & $164(84.5 \%)$ & $244(84.4 \%)$ & $0.68 \ddagger$ \\
\hline Number of increased visual acuity lines* & $5.00(4.72)$ & $3.85(3.22)$ & $<0.01 \dagger$ \\
\hline $\begin{array}{l}\text { Achieved refractive error within } \pm 1 \text { diopter from the intended } \\
\text { refractive error }{ }^{\star *}\end{array}$ & $167(86.1 \%)$ & $267(92.4 \%)$ & $0.03 \ddagger$ \\
\hline Difference between intended and achieved refractive error (diopters) ${ }^{*}$ & $0.56(0.66)$ & $0.43(0.57)$ & $0.02 \dagger$ \\
\hline \multicolumn{4}{|l|}{ * Mean (standard deviation) } \\
\hline \multicolumn{4}{|l|}{${ }^{* *}$ Number and percentage } \\
\hline \multicolumn{4}{|l|}{ † Independent samples t-test } \\
\hline ‡ Chi-square test & & & \\
\hline
\end{tabular}


Table 2

\begin{tabular}{|c|c|c|c|c|c|c|c|c|}
\hline & \multirow[b]{2}{*}{ Q\# } & \multirow{2}{*}{$\begin{array}{l}\text { Control } \\
\text { Group } \\
\mathrm{n}=194\end{array}$} & \multirow{2}{*}{$\begin{array}{c}\text { Experimental } \\
\text { group } \\
\mathrm{n}=289\end{array}$} & \multirow[b]{2}{*}{$P$-value } & \multicolumn{2}{|c|}{$\begin{array}{l}\text { Multiple linear } \\
\text { regression analysis }{ }^{1}\end{array}$} & \multicolumn{2}{|c|}{$\begin{array}{l}\text { Multiple logistic } \\
\text { regression analysis }{ }^{1}\end{array}$} \\
\hline & & & & & $B(S E)$ & $P$-value & OR $(95 \% \mathrm{Cl})$ & $P$-value \\
\hline \multicolumn{9}{|l|}{ Patient experience with ophthalmologists } \\
\hline Communication with ophthalmologist ${ }^{\star}$ & Q1-8 & $3.7(0.4)$ & $3.8(0.4)$ & $0.33 \dagger$ & $0.01(0.04)$ & 0.75 & NA & \\
\hline Global rating - ophthalmologist** & Q9 & $9.1(1.3)$ & $8.9(1.3)$ & $0.07 \dagger$ & $-0.15(0.12)$ & 0.22 & NA & \\
\hline $\begin{array}{l}\text { Yes, enough contact with } \\
\text { ophthalmologist }^{\star \star *}\end{array}$ & Q10 & $187(96.4 \%)$ & $267(92.4 \%)$ & $0.08 \ddagger$ & NA & & $0.51(0.21-1.27)$ & 0.15 \\
\hline \multicolumn{9}{|l|}{ Patient experience with overall care } \\
\hline Global rating - hospital** & Q11 & $9.1(1.3)$ & $9.0(1.0)$ & $0.32 \dagger$ & $-0.01(0.11)$ & 0.95 & NA & \\
\hline Willingness-to-recommend ${ }^{*}$ & Q12 & $3.9(0.3)$ & $3.9(0.4)$ & $0.14 \dagger$ & $-0.05(0.04)$ & 0.21 & NA & \\
\hline \multicolumn{9}{|l|}{ Patient experience with patient education } \\
\hline Yes, emergency information provided ${ }^{\star \star \star}$ & Q13 & $163(84.0 \%)$ & $254(87.9 \%)$ & $0.21 \ddagger$ & NA & & $1.20(0.69-2.10)$ & 0.53 \\
\hline Yes, postoperative instructions provided ${ }^{\star * *}$ & Q14 & $119(61.3 \%)$ & $213(73.7 \%)$ & $<0.01 \ddagger$ & NA & & $1.78(1.18-2.69)$ & $<0.01$ \\
\hline
\end{tabular}

Q\#, Number of the question in questionnaire (see Figure 2); B(SE), Beta coefficient (standard error); OR (95\% Cl), Odds ratio with 95\% confidence interval

* Mean (standard deviation) based on a Likert-scale response scores ranging from 1 (never/definitely not) to 4 (always/definitely)

${ }^{* *}$ Mean (standard deviation) based on a scale ranging from 0 (worst possible care) to 10 (best possible care)

*** Number and percentage of "Yes" responses

$\dagger$ Mann-Whitney test

$\ddagger$ Chi-square test

${ }^{1}$ Statistical testing of the experimental group to the control group (reference group = control group), adjusted for age, health, gender, education, LogMAR equivalent of postoperative corrected distance visual acuity, number of increased visual acuity lines and difference between intended and achieved refractive error in diopters 
Table 3

\begin{tabular}{|c|c|c|c|c|c|c|}
\hline & \multirow[b]{2}{*}{ Q\# } & \multirow{2}{*}{$\begin{array}{l}\text { Control } \\
\text { group } \\
n=194\end{array}$} & \multirow{2}{*}{$\begin{array}{c}\text { Experimental } \\
\text { group } \\
n=289\end{array}$} & \multirow[b]{2}{*}{$P$-value } & \multicolumn{2}{|c|}{$\begin{array}{c}\text { Multiple logistic } \\
\text { regression analysis }\end{array}$} \\
\hline & & & & & OR $(95 \% \mathrm{Cl})$ & $P$-value \\
\hline First-day review conducted by: & & Ophthalmologist & Nurse & & & \\
\hline $\begin{array}{l}\text { Care provider explained things in a } \\
\text { way that was easy to understand }\end{array}$ & Q16 & $182(93.8 \%)$ & $276(95.5 \%)$ & $0.33 \ddagger$ & $1.46(0.62-3.44)$ & 0.38 \\
\hline Care provider listened carefully* & Q17 & $190(97.5 \%)$ & $282(97.6 \%)$ & $0.82 \ddagger$ & $0.79(0.21-2.91)$ & 0.72 \\
\hline Patient felt reassured ${ }^{*}$ & Q18 & $192(99.0 \%)$ & $280(96.8 \%)$ & $0.13 \ddagger$ & $0.34(0.07-1.72)$ & 0.19 \\
\hline Preference for same review method* & Q19 & $139(71.6 \%)$ & $250(86.5 \%)$ & $<0.01 \ddagger$ & $2.39(1.47-3.86)$ & $<0.01$ \\
\hline Final review conducted by: & & Ophthalmologist & Optometrist & & & \\
\hline $\begin{array}{l}\text { Care provider explained things in a } \\
\text { way that was easy to understand }\end{array}$ & Q21 & $176(90.7 \%)$ & $259(89.6 \%)$ & $0.79 \ddagger$ & $0.98(0.47-2.04)$ & 0.97 \\
\hline Care provider listened carefully* & Q22 & $191(98.5 \%)$ & 277 (95.8\%) & $0.12 \ddagger$ & $0.37(0.10-1.39)$ & 0.14 \\
\hline Patient felt reassured ${ }^{*}$ & Q23 & $192(99.0 \%)$ & $280(96.8 \%)$ & $0.15 \ddagger$ & $0.35(0.06-1.87)$ & 0.22 \\
\hline Preference for same review method* & Q24 & $184(94.8 \%)$ & $122(42.2 \%)$ & $<0.01 \ddagger$ & $0.31(0.18-0.53)$ & $<0.01$ \\
\hline
\end{tabular}

Q\#, Number of the question in questionnaire (see Figure 2$)$; OR $(95 \% \mathbf{C l})$, Odds ratio with $95 \%$ confidence interval

* Number and percentage of "Yes" responses

¥ Chi-square test

${ }^{1}$ Statistical testing of the experimental group to the control group (reference group $=$ control group), adjusted for age, health, gender, education, LogMAR equivalent of postoperative corrected distance visual acuity, number of increased visual acuity lines and difference between intended and achieved refractive error in diopters 
Figure 1a

Cohort of $\mathbf{7 6 4 5}$ patients who underwent first eye cataract surgery

between Jan.'07-Sept.'08

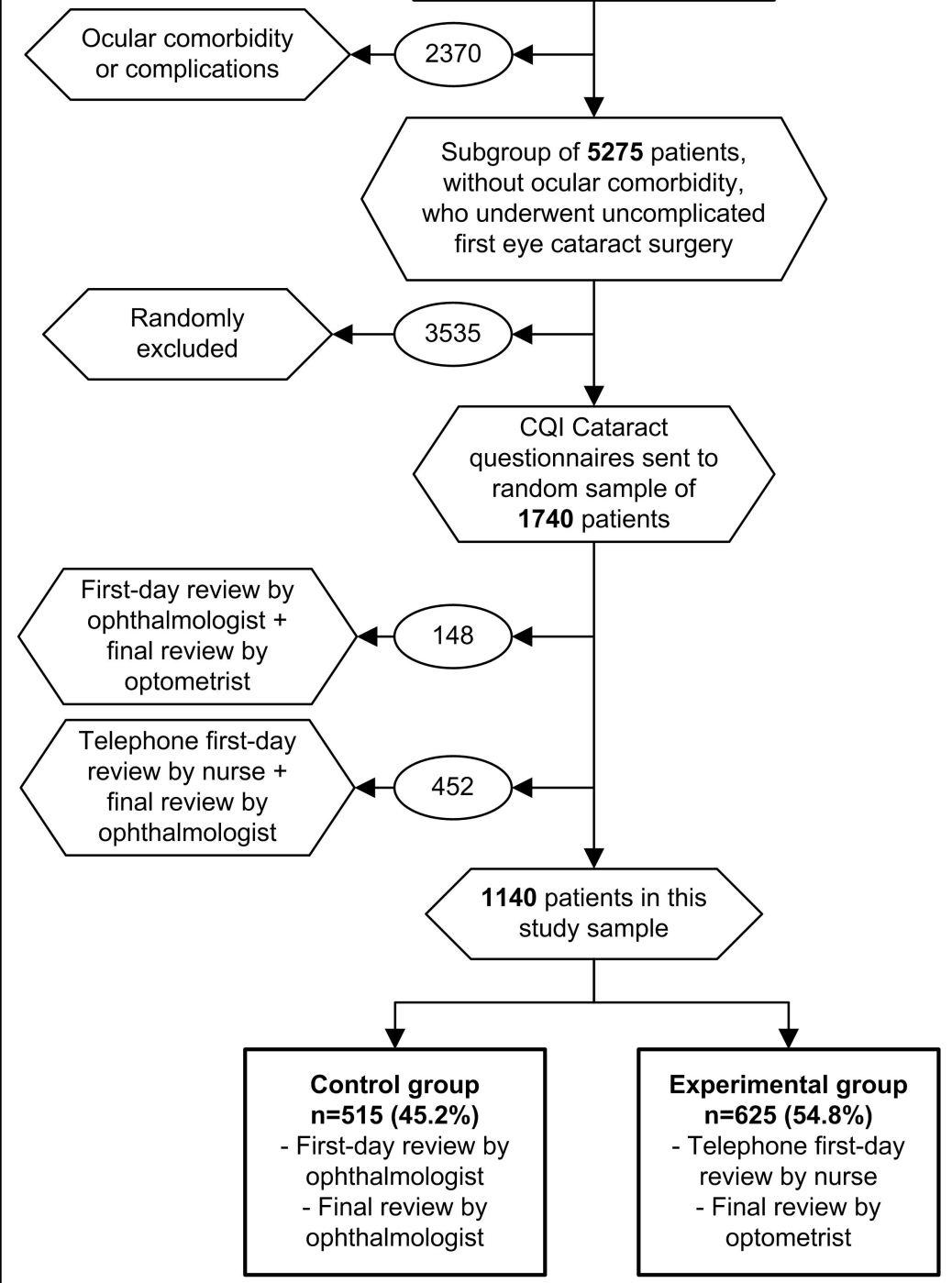

Figure $1 b$

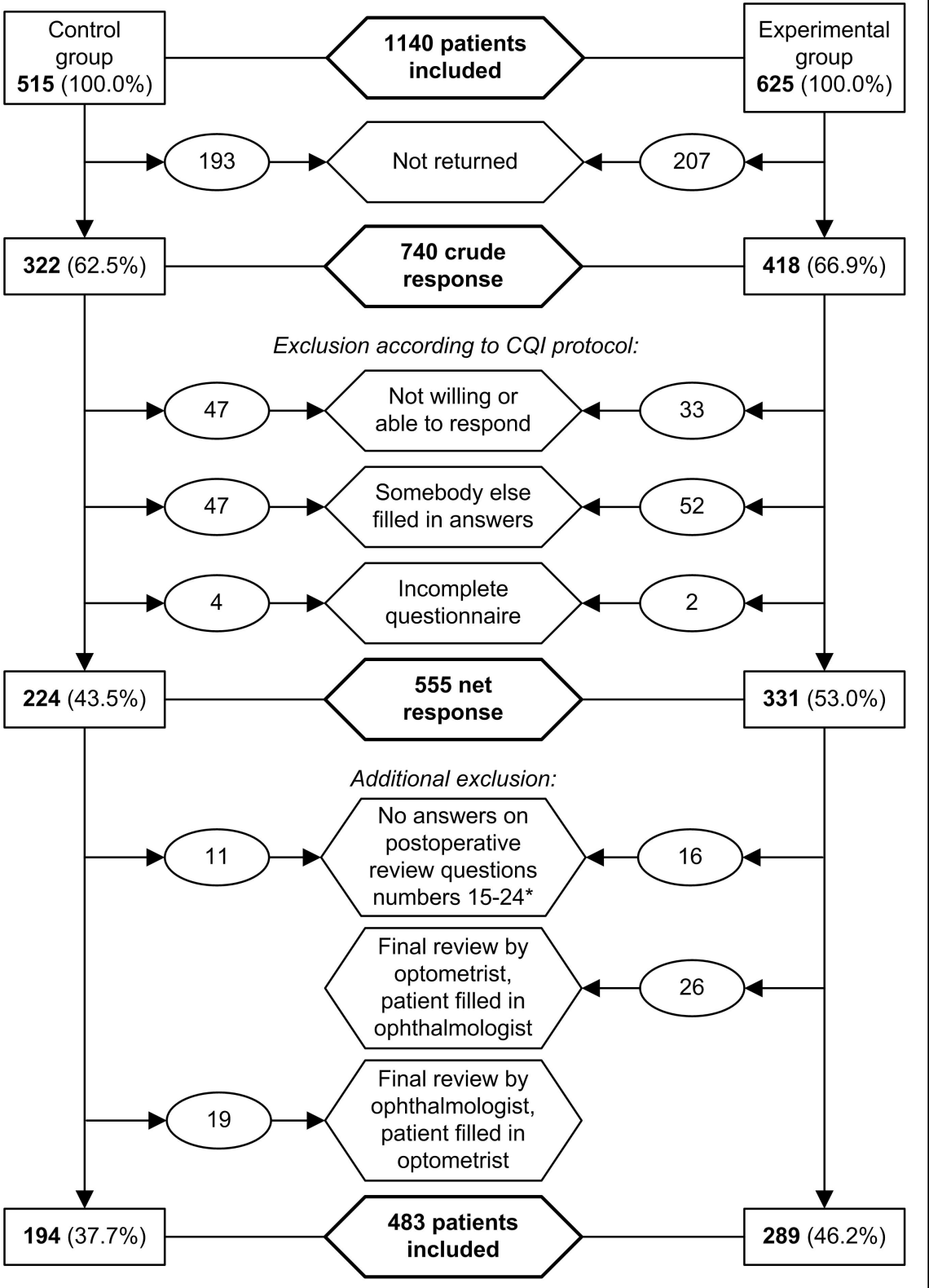




\section{Ophthalmologists}

Q1 How often did your ophthalmologist treat you with respect?

$\square 1$ Never; $\square 2$ Sometimes; $\square 3$ Often; $\square 4$ Always

Q2 How often did your ophthalmologist listen carefully to you?

$\square 1$ Never; $\square 2$ Sometimes; $\square 3$ Often; $\square 4$ Always

Q3 How often did your ophthalmologist explain things in a way that was easy to understand?

$\square 1$ Never; $\square 2$ Sometimes; $\square 3$ Often; $\square 4$ Always

Q4 How often did your ophthalmologist spend enough time with you?

$\square 1$ Never; $\square 2$ Sometimes; $\square 3$ Often; $\square 4$ Always

Q5 How often did your ophthalmologist go seriously into merits of your questions?

$\square 1$ Never; $\square 2$ Sometimes; $\square 3$ Often; $\square 4$ Always

Q6 How often did your ophthalmologist share decision making?

$\square 1$ Never; $\square 2$ Sometimes; $\square 3$ Often; $\square 4$ Always

Q7 How often did your ophthalmologist take specific wishes into account?

$\square 1$ Never; $\square 2$ Sometimes; $\square 3$ Often; $\square 4$ Always

Q8 How often did your ophthalmologist talk about things that went wrong?

$\square 1$ Never; $\square 2$ Sometimes; $\square 3$ Often; $\square 4$ Always

Q9 Using any number from 0 to 10 , where 0 is the worst care possible and 10 is the best care possible, what number would you use to rate the overall care delivery of your ophthalmologist?

0 (worst possible care) $-1-2-3-4-5-6-7-8-9-10$ (best possible care)

Q10 Did you have enough contact with your ophthalmologist during your cataract treatment?

$\square$ Yes; $\square$ No

\section{Overall care in hospital}

Q11 Using any number from 0 to 10 , where 0 is the worst hospital and 10 is the best hospital, what number would you use to rate the hospital?

0 (worst possible hospital) $-1-2-3-4-5-6-7-8-9-10$ (best possible hospital)

Q12 Would you recommend this hospital to your friends and family?

$\square 1$ Definitely not; $\square 2$ Probably not; $\square 3$ Probably yes; $\square 4$ Absolutely

\section{Patient education}

Q13 Did you receive information about what to do in case of emergency problems?

$\square$ Yes; $\square$ No

Q14 Did you get information about what symptoms or health problems to look out for after you left the hospital? $\square$ Yes; $\square$ No

\section{First-day review}

Q15 What review did you receive one day after surgery?*

$\square$ I visited the hospital; $\square$ A nurse called me

Q16 How often did your ophthalmologist / the nurse explain things in a way that was easy to understand?*

$\square$ Never; $\square$ Sometimes; $\square$ Often; $\square$ Always

Q17 How often did your ophthalmologist / the nurse listen carefully to you?*

$\square$ Never; $\square$ Sometimes; $\square$ Often; $\square$ Always

Q18 Did you feel reassured after the review by your ophthalmologist / after the telephone review by the nurse / one day after surgery without receiving a review?*

$\square$ Yes; $\square$ No

Q19 What first-day review would you prefer for a future second eye cataract surgery?*

$\square$ Review in the hospital by the ophthalmologist; $\square$ Telephone review by a nurse; $\square$ Self-review

\section{Final review 4 weeks after surgery}

Q20 Who conducted your review four weeks after surgery?*

$\square$ My ophthalmologist; $\square$ An optometrist

Q21 How often did your ophthalmologist / the optometrist explain things in a way that was easy to understand?* $\square$ Never; $\square$ Sometimes; $\square$ Often; $\square$ Always

Q22 How often did your ophthalmologist / the optometrist listen carefully to you?*

$\square$ Never; $\square$ Sometimes; $\square$ Often; $\square$ Always

Q23 Did you feel reassured after the review by your ophthalmologist / the optometrist?*

$\square$ Yes; $\square$ No

Q24 What final review would you prefer for a future second eye cataract surgery?* $\square$ Review by an ophthalmologist; $\square$ Review by an optometrist

\section{Patient characteristics}

Q25 In general, how would you rate your overall health?

$\square$ Excellent; $\square$ Very good; $\square$ Good; $\square$ Fair; $\square$ Poor

Q26 What is the highest level or grade of school that you have completed?

$\square 8^{\text {th }}$ grade or less; $\square$ Some high school, but did not graduate; $\square$ High school; $\square$ Bachelor study; $\square$ Master study 